\title{
An Analysis of History, Causality and Evolution in Islamic, Iranian and Polish Philosophy
}

\author{
Mohammadreza Shahidipak \\ Department of Humanity, Islamic Azad University, Central Tehran Branch, Tehran, Iran \\ Email address: \\ Reza2018mreza@gmail.com
}

\section{To cite this article:}

Mohammadreza Shahidipak. An Analysis of History, Causality and Evolution in Islamic, Iranian and Polish Philosophy. International Journal of Philosophy. Special Issue: Evolutionity. Vol. 8, No. 4, 2020, pp. 104-111. doi: 10.11648/j.ijp.20200804.14

Received: October 28, 2020; Accepted: November 26, 2020; Published: December 31, 2020

\begin{abstract}
The historical issue of the clash of civilizations from traditional to postmodern has led to emergence of reactionary and evolutionary ideas. My goal is to compare the philosophy of history in Polish Catholic and Iranian Islamic philosophical schools. Avicenna, AL-Farabi, Ibn Muskawiyyah, Averroes, Ibn Khaldun have presented political hypotheses about the progress of history and its degeneration, and they discovered laws governing history that are the key for analysis causality in history. The end of history in Shiite and Catholic thought, is related to the emergence of an expected man, a Savior, who gives a meaning and significance to religion, politics, sociology, and brings a society to perfection. The belief in Jesus in Christianity as an expected Man is the cause of progress and social changes. This evolutionary approach in the form of Messianism and issue of evolution are the main topics of religious philosophy. It is common to Iranian and Polish political philosophy to consider the unseen unity of existence. A significant trace of Polish thought about philosophy of history has emerged in the post-Hegelian philosophy of August Cieszkowski (1814-1894), who called his philosophy of history "historiosophy". It is based on the acceptance of unseen world. Concepts of causality in ideas based on stillness of history and Marxism and any other materialist thinking that do not believe in the unseen or the spiritual have never completely convinced Iranian and Polish thinkers. Among contemporary Polish philosophers W. Julian Korab-Karpowicz has focused on the issue of evolution. He is an interpreter of the philosophy of Josef Hoene-Wronski (1778-1853), who was the founder of independent school of Polish religious philosophy in 19th century and has developed the concept of Messianism. In many of his works, Korab-Karpowicz has criticized philosophical systems of communism, liberalism, and capitalism in the context of the Catholic Christian thought whose influence has continued in Poland in the postmodern period. He has also referred to the philosophical work of Al-Farabi. The result of Al-Farabi's classical philosophy is thus an influence on two philosophical systems, both Western and Eastern, whose practical outcome is a theory of evolution. It is because Al-Farabi has set theoretical foundations of progressive and degenerative processes in societies. His work is like a gold mine of political philosophy based on Plato, Aristotle and Islamic political philosophy from which the rules governing evolution can be extracted. This influence can be seen as an inspiration of Korab-Karpowicz's ideas of human evolution and attainment of happiness. They are fully compatible with theoretical foundations of Al-Farabi political philosophy.
\end{abstract}

Keywords: Civilizations Clash, Historiosophy, Messianism, Polish and Islamic Political Philosophy, Human Evolution

\section{Introduction: Historical Contexts of Philosophical Thought, Common Feeling in History}

\subsection{Historical Similarities Between the History of Iran and Poland During the Medieval and Modern Periods, the Catalyst for Evolution and Degeneration}

The history of progress in countries, if plotted, shows a large curve of continuous cycles of evolution and decline. The case study is two countries in Europe and Asia that have a long history. The philosophical issue of evolution, which has had many political implications, has been studied in these strategic regions of the world. Iran and Poland had in ancient times a similar empire history with foreign occupation, border problems and growing culture. Poland emerged as a state after antiquity [1] and in the early Middle Ages faced three Mongol invasions (1240-1241, 1259-1260 and 1287-1288), and throughout centuries was engaged in many wars to defends its 
territory to be finally divided and occupied by Russia, Austria and Prussia in the late eighteenth century. It has emerged again as a country after the World War I when it fought a war of independence. During the World War II it was divided again between Germany and Soviet Russia and was occupied suffering terrible human life loss and its borders subsequently have changed [2]. The history of Iran was also marked by many invasions and occupations by foreign forces. Consequently, these political and military events may have created similar economic and cultural conditions and could have a similar impact on religion in two countries. Both countries would frequently engage actively to free themselves from occupation. On this influence of political events similar ideological and political aspects of religion have developed in both countries, even if main religions were different.

In addition, some historical links between Poland and Iran have developed. During the nineteenth century and during the World War II, because of foreign occupation, many Polish people migrated to Iran and some of them settled there permanently, got married and were ultimately assimilated into Iranian society. We also some similar historical events related to both countries, such as occupation of Iran and Poland, especially in the twentieth century history. Due to the strategic position of Iran in the First World War, it began on November 7, 1914 with the landing of British troops in the Shatt al-Arab near Iranian border. Then, according to most Western historians, the Second World War began on September 1, 1939, with the Nazi Germany invasion of Poland, of which the symbol was Westerplatte, a peninsula at the port of Gdansk (Danzig), which was then a free city administered by the League of Nations.

Even this brief historical introduction points us to some historic and cultural similarities, and is a good starting point for initiating my research. Because of foreign intrusion, in the modern era, the two countries went through occupation and hardship, and have entered into a period of decline. One of sub-issues of this research is related to the question whether it is possible to philosophically analyze evolution and degeneration in contemporary world, taking Poland and Iran as examples. Researchers often believe in inefficiency of philosophy in analyzing evolution and degeneration, and yet I want to prove that philosophical approach can be very productive.

\subsection{The Death of Philosophy and Philosophy of History and Survival of Politics and Inefficiency of Humanities}

The greatest wonder of our times is the fact of our quick development technological and scientific development. The human progress is far greater today than our evolution during earlier centuries. The phenomenon of human progress is a result of the development of human sciences that began with Immanuel Kant and August Kompt and ended with Bernard Russell and Ludwig Wittgenstein in twentieth century. Then a sharp decline followed. The rate of decline that occurred in the late twentieth century and continues until this century is much greater than earlier. Much research has still to be done on the failure of modern humanities to prevent their degeneration in age of progress. Their decline was paralleled by two world wars. Having gone through atrocities of the World War I, European humanists, like Jose Ortega y Gasset or Martin Heidegger, and political leaders did not learn enough from history to stop the World War II.

Intellectual background of such a stalemate in Western human behavior can be identified with the poverty of philosophy of that times and its slow death, which was the result of the defeat of traditional humanistic philosophical schools against the onslaught of both positivism and existentialism. At a political level, the historical manifestation of this philosophical defeat is the political behavior of radical parties against liberal and democratic ideas. The most striking example is the Nazi party in Germany, which rejected the humanistic values of the European liberal and democratic tradition and whose proponents completed German philosophy by bringing it to the point of a radical political ideology. While Martin Heidegger could be seen here as providing some useful philosophical tools [3], it was in fact the German political leader, Adolf Hitler whose party in the 1930's carried out gradual abolition of Versailles and eventually violated peace treaties, forcing the democratic leaders to accept his demands, thus paving way for the World War II. And in the end, the revival of fascism placed on some existentialist philosophical background placed Western democracies between war and surrender. Whether we still will face a similar case in the future is uncertain because one cannot learn completely from history-lessons of history cannot be exactly repeated. And yet, we can only hope that we have now learned more on human evolution and decline.

\subsection{Changing View of Philosophy: An Analytic Approach}

The possibility of a philosophical study of human evolution and decline has been investigated by a number of scholars and philosophers in Iran and Poland. It is also worth mentioning that the crucial role in the world transformation was played by the emergence of two famous analytic philosophical schools. The First was the Lvov-Warsaw School that developed a new approach to anthropology and philosophy based on a critique of previous ideas and schools. Influenced also by Polish thinkers, especially in logical thinking, such as Jan Lukasiewicz or Alfred Tarski [4], the School attempted to develop a scientific approach to philosophy. Nevertheless, it did not completely part with the classical humanist approach. The philosophers gathered around the Lvov-Warsaw school had diverse research interests, including ontology and ethics. The second school, the Vienna Circle was a group of early twentieth-century Austrian philosophers who sought to reconceptualize empiricism and has been hailed as inspiring an intellectual revolution of twentieth century. They were highly critical of existentialism and similar philosophical trends and advocated logical and critical thinking. They insisted that the meaningful use of language has its reference in objects that it names and these objects must be accessed by direct sense experience. However, such an approach would make the final damage to the humanist world-view because it would classify normative moral and political philosophy advocating a conception of the human good as a pseudo subject [5]. 


\section{The Philosophy of Progress and the Question of Evaluation}

The question of evolution in the classical Greek period has become the focus of many philosophical studies. The works of Aristotle can be seen as the gateway to the transition from pre-Socratic period to classical Greek era. In his ontological works he offered a philosophical interpretation of becoming and of completion based on some logical propositions. Then, in his political philosophy he described the purpose of establishing a state as a tool to perfect human society in order to achieve happiness, a good life. He and Plato can be regarded as paradigm humanist philosophers His ideas ware carried further by Christian philosopher-theologians, especially by St. Thomas Aquinas during the Medieval Times. While Modernity is an epoch marked by a departure from the philosophical ideas of Aristotle, the questions of becoming and of human evolution must again be asked.

\subsection{The Development of the Philosophy of History Through the Concept of the Clash of Civilizations}

One of the pillar movement of history takes a form of the clash of civilizations. The medieval history, marked by the Crusades, brings the clash of civilizations to the world stage. This issue, as it occurs in Polish philosophy and Islamic philosophy can be discussed within the framework of ideas formulated in theology and systematic philosophy. It has religious roots in Catholic religion and Shiite religion. Avicenna, AL-Farabi, Ibn Muskawiyyah, Ibn Khaldun [6] have all presented special hypotheses about history, discussed the concept, nature and function of causality, and discovered the traditions and laws explaining the course of clash of civilizations.

\subsection{Flow of Philosophy of Progress and Evaluation in Modern, Scientific Evolution}

In the modern era, the clash of cultures and civilizations was studied by many scholars from different perspectives. Bernard Lewis came to conclusion that the clash of civilizations can also lead to the development and transmission of a civilization. For example, by engaging with the ancient works of Plato and Aristotle, the Islamic scholars, whose works were known in Europe, became a suitable passage for the transfer of Western civilization from ancient times to the Middle Ages. In many of his works, Arnold Toynbee has studied the twenty-three civilizations in the context of their interactions [7]. Will Durant has written on the course of civilization by looking at the idea of progress [8]. Then, the author of this article focuses on the impact of the Islamic civilization on the Christian world in the Middle Ages, which has been related to the translation to Latin from Arabic of many ancient Greek works of philosophy and took place through led to a civilizational transfer from Muslim to European countries [9-12].

In the later modern period, humanities had become dominated by the positivist methods and even philosophy and theology were influenced by the use of empirical approach to study history, society, morality. One of hallmarks of modern materialism is the material definition of evolution that has been accepted in all humanities. Marxism, based on denial of metaphysics, classified all human sciences, which used classical method of philosophy, as an "unscientific reaction." Today the mainstream of modern social research around the world tries to establish utopia on basis of scientific ethics and scientific cognition. The impact of this claim puts the world at risk of dehumanization. This is the danger of emptiness affecting man and society without any identity and now in the postmodern times there is a feeling of scarcity by many humanities experts, who project their scientific hypotheses to compensate for the emptiness and shortage that modernity has created in field of theoretical cognition and human behavior.

\section{The Problem, Method, Hypothesis}

\subsection{The Clash of Civilizations and Progress}

The main issue in my current research is related to the question of progress in history. In particular, I want to determine which system of thought is able to correctly conceptualize human evolution. Because in every historical period, people coming from different countries have differed views in determining instances of progress, different ideas emerged as to determine the nature of human evolution and philosophers, politicians, and historians throughout history have presented their hypotheses. The historical problem to consider is for us the continuous civilizations clash from the ancient to postmodern era. My hypothesis is that history is not over yet and continues to develop in a broad sense of a clash of civilizations, in form of evolution. The question worth asking is: Has the establishment of national philosophies in some European and Middle Eastern countries within the framework of continental philosophy resulted in the development of civilization and culture? Has it prevented the influence of intellectual imperialism, and brought to nations cultural freedom, independence, and democracy? To answer this question, I will now compare and analyze the common roots of cognition and episteme of history and evolution in Polish and Iranian philosophical schools, as well as in Islamic philosophy in general. Fundamental question that this article addresses is whether evolution is a historical, socio-political matter or a philosophical concept.

\subsection{The System of Political Philosophy of Islam and Iran}

There are many systems of thought that can be helpful to study the issue of evolution. One of the most successful of these systems is the system of Islamic philosophy. Islamic philosophy consists of efforts of great philosophers who developed the earlier Greek philosophical thought and added new issues to the world philosophy. Thus, their philosophy became at some point a global paradigm and an international way of philosophical thinking. AL-Farabi, Averroes, Avicenna are not only Islamic philosophers. They are also 
eternal figures of the world philosophy and people of immortal wisdom. Following this tradition, the system of political philosophy in Iran and Islamic world is based on four social philosophical principles:

\subsection{Paradigm of Social, Individual Nature from Aristotle to Avicenna}

Al-Isharat wal-Tanbihat (Remarks and Admonitions) is one of the important works of Ibn Sina (Avicenna, 980-1037). Grounded in an exploration of logic, which Avicenna regarded as the gate to knowledge, and happiness, which was for him, as for Aristotle, the ultimate goal of human life, the text illuminates the divine, the human being, and the nature of things through a wide-ranging discussion of topics [13]. The sociality of human beings and need for each other is called principle of employment. This principle has been described in a very detailed form by Avicenna based on monotheistic interpretation of Greek philosophy. He has presented Aristotle's view on this issue from an Islamic perspective - Iranian philosophy. In Aristotle, the city-state as a social unit, is the subject of political philosophy [14]. City is a place of human origin and human evolution; Avicenna in monotheistic and metaphysical interpretation of Aristotle's philosophy developed a type of realist metaphysics.

\subsection{The Universal Paradigm of Truth the Hypothesis of Averroes}

According to Averroes's philosophical hypothesis, evolution is a function of philosophical thought about truth. There are two: rational truth and religious truth. The principle of existence of truth, which has played an important role in philosophical systems, was compiled in Islamic philosophy seven hundred years ago by Averroes and his work was then translated into all European languages [15]. Averroes is famous in Europe because of his study of Aristotle. He translated many Aristotelian works into Arabic and revived them by his commentaries and thus preserved them. European medieval philosophers gave Averroes the title of the Commentator [16] The central theme of Averroes's political philosophy is the individual and the city (state). He represents a paradigmatic Islamic political philosophy in his commentary on Plato's Republic [17]. He considered the Republic as basis of his political science, translated this Platonic work into Arabic seven centuries ago and considered its ides as intersensory for the knowledge of politics.

\subsection{Philosophical Sociology of Al-Farbi}

According to Al-Farabi's socio-political philosophy, evolution of individual is related to the development of city (state) and it is social phenomena. In proposing the development of society and the education of the individual, Al-Farabi used the philosophy of Aristotle and Plato [18]. He combined Aristotle's realist metaphysics with Plato's idealist metaphysics and, based on some ideas of Plato's political philosophy, categorized individuals and societies. The central theme of Al-Farabi's philosophy is city's evolution [19].

\subsection{Poland's Messianism Against Positivism and Materialism, Common Hypothesis}

The idea of messianism in Christianity that is related to the expectation of the Savior or the world transformation to the Kingdom of God is a specific idea of the heavenly or religious nations, and this belief is central to the systematic theology of Islam, Christianity and Judaism. In Iran and the Islamic world, Messianic is referred to as Mahdism or Mahdaviyat. In fact, Mahdism is a kind of messianism. It is the establishment of an utopia at the end of times with the advent of the perfect human being [20]. In thought of Avicenna and Al-Farabi, a perfect society and the city of virtue are achieved with victory of philosophy and the rule of the perfect reason. This emergence of ideal state in the systematic Islamic and Christian theology is based on common axis of Christianity and Islam [21]. The philosophical roots of Islamic Messianism and Mahdism go back to the philosophical thought of Plato and Aristotle, and then to the works of Avicenna and Al-Farabi, who show how the human soul has evolved. In the thought of Plato, which is the root of meta-philosophical thoughts, it refers to the necessity of existence of the superior human being. Aristotle has shown this superiority in the essential and inherent classification of man into three categories of bronze, silver and gold, of whom gold is the most perfect, and Avicenna and Al-Farabi have described it as a perfect human with a monotheistic interpretation in the form of systematic Shiite theology. Ibn Tufayl and Ibn Bajah and Averroes, following Averroes has described him as an awake living human being.

\section{The Tradition of Polish Philosophy}

Polish philosophy is one of the European philosophical systems that has deep historical roots. It has developed as a result of continuous interaction of different schools of thought in Europe which gives rise to German, French, Italian, British, as well as to Polish philosophy. In the tradition of Polish philosophy one can distinguish at least four main branches.

\subsection{Polish Analytical Philosophy}

The Polish Lvov-Warsaw School that developed in the early twentieth century gathered a number of Polish philosophers and logicians some of whom, like Alfred Tarski, have become the most influential philosophical figures in twentieth century philosophy. Because of their influence they can be considered equally important as the representatives of the analytic philosophy related to the Vienna circle [22]. The process of forming the continental analytic philosophy was influenced in Poland by some epistemological concepts related to German idealism, as well as by English realist philosophy. In addition, it has been placed in a powerful religious context of Catholic religion and of Polish messianism. Hence, Polish analytic philosophers would never embrace atheism or materialism. They have earned a special place in continental philosophy due to presentation of a special paradigm in scientific method of philosophy using logic and mathematics, and yet, they would also be interested 
in ethics and moral issues. Thus, Polish analytic philosophers sought to create an inclusive philosophical system that would escape the positivist tendency to reduce philosophy and reject materialism in an attempt to be prepared to ask deep philosophical and ethical questions. Tadeusz Kotarbinski, who is regarded by some scholars as Bernard Russell of Polish philosophers-logicians from the Lvov -Warsaw school, as well as philosophers and logicans Jan Lukasiewicz, Stanislaw Lesniewski and Alfred Tarski, are the cornerstones of Polish analytic philosophy [23-25].

\subsection{Philosophy of Religion in Context of Polish Messianic Paradigm}

The Catholic Christianity in Poland is a historical example for the influence of religion in field of philosophy [26]. The idea of Messianism has deep philosophic and religious roots in Polish thought. A specific philosophical form of Messianism emerged in Polish philosophy in the nineteenth century due to influence of Fichte and German idealism, but was placed in a specific Polish intellectual context. Of the special importance is here the philosophy of Josef Hoene-Wronski, who was a genius mathematician and philosopher, and introduced the concept of Messianism to Polish philosophy. His conception of the philosophy of history, in which he describes the idea of human evolution, is based on mathematical rule of creation, the end of which is the proclamation of absolute religion. Hoene-Wronski's philosophy form a grand system and is one of systematic types of philosophy of religion in nineteenth century [27-28]. We find the continuation of his ideas in the work of the contemporary Polish philosopher W. Julian Korab-Karpowicz.

\subsection{Changing View of Philosophy: Non-western View of Man, Non-european Anthropology}

We can find in Polish thought a remarkable revolution concerning the view of man that is different from the mainstream Western view of man that is still Eurocentric. This change in attitude is represented by the Polish school of anthropology and especially by Bronislaw Malinowski [29]. A critique of European self-centered civilization is one aspects of contemporary anthropology, which is a part of the most advanced humanities in West. Malinowski, a Polish anthropologist and philosopher produced great works in which he challenged the one-sided authority of the West in culture. He concluded his extensive empirical research with the statement that every culture is a whole and every culture is a complex structure that is used to meet the basic needs of man and each culture has its own value. Unlike many of his Western colleagues and in the correspondence to the character of Polish philosophy, he would appreciate the value of religion. "In reality and historically", he says, it is faith that brings about the brotherhood of man and gives celestial freedom" [30]. The functionalist revolution in anthropology, which Malinowski initiated, challenged the superiority of European culture, and is now regarded as the principle of cultural relativism, accepted by most sociologists. According to Malinowski's hypothesis, each group of human beings has its own culture and their evolution takes place in the context of their own culture.

\section{The Convergence of Iranian and Polish Philosophy: From Al-Farabi to Korab-Karpowicz}

\subsection{Historiosophy--Cieszkowski's Philosophy}

Great historical changes, which have an international dimension and have made a great influence on life in Poland, have caused Polish philosophers to pay special attention to history. In the nineteenth century they presented several philosophical systems based on evolutionary theories. A significant contribution to philosophy of history was made by Joseph Hoene-Wroński (1778-1853) and by his younger contemporary August Cieszkowski (1814-1894). He called his philosophy of history "historiosophy." Like a large part of Islamic and Iranian philosophy, Cieszkowski's philosophy has a form of Messianism [31].

\subsection{Application of the Evolutionary Idea in Contemporary Polish Philosophy}

Human evolution and the establishment of the perfect city and the education of the good citizen are ideas that we can find in the classical works of Plato and Aristotle. But Al-Farabi's book entitled On the Perfect State is first work that comprehensively deals with the subject [32]. Many contemporary scholars still analyze and explain historical progress of societies by using insights of Al-Farabi. The research on well-being of individuals and a happy society has a historical background, stretching from antiquity to the middle Ages.

W. Julian Korab-Karpowicz, a contemporary scholar and philosopher, has studied Al Farabi's great work and the issue of prosperous societies. His book, Tractatus Politico-Philosophicus (Political-Philosophical Treatise), which has been written in short numbered paragraphs and published in 2017 by Routledge has an universal and timeless quality [33]. This work, which has now also been translated to Arabic, shows that universal philosophy in Poland is still alive and can bring fruits that can be appreciated globally In this book, Korab-Karpowicz presents a new paradigm for the contemporary political philosophy. He takes a brief look at important issues in political philosophy, especially the idea of politics, solidarity and freedom, and includes its essential topics such as civilization, evolution, freedom, justice, and political rationality. His definition of politics, as the art of governance, and its purpose, which is happiness, are the same as we can find in political works of Al-Farabi and other Islamic thinkers, whose purpose is, like him, to ensure human wellbeing in societies. His practical rules for providing security to citizens are related to the teachings of Christianity and Islam, and indicate the importance of the political power in providing social peace in societies, so that people can achieve higher life ends. According to Korab-Karpowicz, the 
ultimate goal of society is practical moral perfection of individuals and end of society is to ensure happiness, our self-fulfillment, which is also a religious life goal. The fourth rule for a happy society is a proper education system. It must be so designed that it provides a lasting impact on our moral and intellectual excellence. But the most important aspect of social organization to ensure happiness and peace for all is cooperation, which Korab-Karpowicz calls the first principle of humankind. In short nothing of a lasting value can be achieved by conflict whether domestic or international. Hence our conflict striven humanity of today must rediscover values of cooperation and social harmony. And our today's deficient societies must continue to live by the philosophy of hope for the emergence of virtues and happiness in future.

Among contemporary Polish philosophers W. Julian Korab-Karpowicz is also a unique interpreter of Hoene-Wronski's philosophy and expands his theory of human evolution. He claims that we shall overcome the current age of violent conflict and in the end come to the age of humanity's perfection. This way we shall transit from today's post-Modernity to a new age of Evolutionity, when human beings shall consciously engage in their moral and intellectual improvement, and engage in self-conscious evolution. Korab-Karpowicz's ideas have emerged from the background of the Catholic Christianity and are a bold attempt to overcome the materialistic concepts of the Western philosophies of liberalism, capitalism and communism in the world which has now moved more intensely to a postmodern period. He gives us an idea and hope for Evolutionity, a new evolutionary age or "a new evolutionary epoch, which would replace modernity and postmodernity" [34].

\section{Findings, Discussion, Convergence of Two Philosophical Systems: Polish Catholic and Shiite Islamic}

There are many common points to philosophical system of Iran and Poland, and this is clearly visible in our contemporary world which because of its materialism can easily bring an end to philosophy and any other spiritual purists. The question arises as to why in spite of the materialistic tendencies, Polish national philosophy and Islamic and Iranian philosophy are still alive as a humanist enterprise? Some scholars have studied the issue of the uniqueness of Polish philosophy that have helped it to survive [35]. A preliminary answer to this survival question is: the lasting importance of the Polish school of philosophy is similar to that of Islamic philosophical system on history and its evolution. These philosophes have not rejected religion and faith is continuing to be their spiritual source, and this has saved them from the contemporary destructive materialist trends. In these two philosophical messianic systems, in Shiite and Polish Catholic, the end of history is emergence of an expected Man in the form of Messiah and an emergence of a perfect society - the Kingdom of God on earth. Further, there is a belief in a kind of unity of existence and evolutional order in world, especially in an evolutionary progress of history as in the Polish philosophical school. In these two philosophical systems, Islamic Shiite and Polish Catholic, the end is perfection, moral and intellectual. This belief in a historical destiny and a perfect end brings the unity of existence and an order in the world.

This concept of the final world order is strongly expressed in the concept of evolution developed in the Polish philosophical school, especially by philosophers, such as Hoene-Wronski, Cieszkowski and recently Korab-Karpowicz In the age of conflict, different religions have so far caused divisions among human beings. However, at the end of history we are finally all reconciled in form of a ummah which is a symbol of a perfect, universal society. Yet to reach this perfect end the ummah cannot be imposed by a fundamentalist political force because using force is always related to opposition and conflict. The perfect end can only be achieved by a systematic moral and intellectual transformation. It can be established only on the values of the good and the truth.

The common denominator of the Polish political philosophy and the political philosophy of Islam is the difference between nation and ummah, that is, people with a common will. Ultimately, we, as human beings, transit from a nation to ummah. Yet at certain point of our evolution a nation may be needed. Polish philosophers have often emphasized the importance of a nation. On its local, national basis, the realization of the whole humanity and the evolution of human values, in a form of perfection, are possible. Yet, in the end, we aim at a perfect ummah. Ummah (English "Community" Polish "Wspolnota") is a common concept in Shiite political philosophy and Catholic political philosophy and theology.

Consequently, the common ground of philosophical thought in Iran and Poland is deeply grounded in the concept of Community and is profoundly religious. This contributes to its lasting quality. In addition to deep religious roots, these philosophical ideas have a human depth. The purpose of this article is to stress a common intellectual background on which the future Iran-Poland relations can be built, as well better human relationships for the whole humanity. There is a great value in deepening and strengthening existing cultural roots in philosophy, and in contributing to the eternal wisdom, which belongs to the whole human race.

For reason of the deep spiritual and religious component of Iranian and Polish philosophy, materialistic conceptions of evolution and the end of history or hypotheses based on determinism, such as we find in Marxist philosophy have failed to attract scholars in Iran and Poland, and have never become included in the national system of philosophy and thought. Like liberal ideas, they could only be a foreign import. The concept of causality based on the idea of stillness of history or the historical determinism that we find in Marxism have never completely influenced Iranian and Polish minds. In Iran, Marxist thought has been criticized by many contemporary writers. A similar critique we can find in Poland. In the Militia and Militarism published in 1899, Rosa Luxemburg reproached German militarism and imperialism strongly. While she was not a religious thinker, but rather a revolutionary, her ideas coming from her Polish background 
had high moral qualities. Hence, the belief in Jesus Christ and the expected Man as a historical cause and driving force of the progress in history has a special place in Iranian and Polish philosophical thought, and has influenced progressive thinkers.

This is why we can regard the Polish philosophical system is being very close to Islamic philosophy, particularly in their agreement between reason and faith, and in their belief in a dual truth It is because, according to contemporary Polish philosophers, philosophy is related to the balanced use of reason and faith needs understanding, so that the human mind does not fall into the trap of Western rationalism and enlightenment [36]. Breaking down power of positivism and scientism and taking it out as a way of philosophical study has also made an impact on the Frankfurt school and its critical theory [37]. However, Polish philosophy is different and unique because it has preserved a strong religious element.

This rejection of scientism has become prevalent in postmodern period. In contemporary Polish philosophy it is not a mere rejection. There is a call to classical rationality that goes back to Aristotelian realism and Platonic idealism. In postmodernism we can sense a combination of reason and emotion as in Spinoza's philosophy and, in general, this path of summing up the rational and emotional elements is very characteristic of the postmodern period. Yet, Polish contemporary philosophy goes beyond this elusive postmodern synthesis to classical rationality, and ultimately it aims at Evolutionity.

\section{Product and Benefit, Today's Tendency to Work Back to Middle Ages Is a Way Back to AL-Farabi's Philosophy}

Ultimately, the validity of any philosophy is its practical application. Korab-Karpowicz, who has so brilliantly developed further the idea of human evolution and introduced the concept of Evolutionity, is one of Poland's most outstanding contemporary thinkers. He has produced works on how to apply philosophical ideas to control social and international crises, preventing war, and establishing lasting peace. He has proposed the concept of virtue in history in order to present the way of human evolution in history and has described seven pillars of virtue in happy societies. As he has appreciated the philosophy of Al Farabi and built his philosophy on some of his key insights, his work Tractatus Politico-Philosophicus should be widely read, especially among Muslim scholars. His ideas of a perfect state and of a happy society have a great value for us today living in a largely conflicting and turbulent political environment. He brings back to our consciousness the highest ideas of humanity.

With these words I conclude my research. I have attempted to prove the virtues of ancient traditions governing both Islamic philosophy and in Polish philosophy are not yet over. One could even think that it is from these countries: Poland and Iran that would come a civilizational revival that we contemporary humans so much need. The fact that Korab-Karpowicz uses the ideas of Al-Farabi in his works makes me believe that we can build a bridge between Polish and Iranian philosophical traditions, and this bridge would benefit the whole humanity. It is important that we look for ideas, even for utopias, and are able to classify societies into ideal, misguided and corrupt. And the notion of progress to a final end is common paradigm in the system of Islamic and Polish philosophy. It points to the idea of history as a turbulent and continuous encounter between good and evil societies until emergence of the absolute goodness and truth.

The emergence of some philosophical concepts in literature, poetry and film in Iran and Poland is a sign of practical implementation of this eternal idea., The presence of political philosophy at level of media and literature in a paradigm presented by Tractatus Politico-Philosophicus is a sign of the book's success in presenting a practical vision based on international language of philosophy. The question remains whether the value of the Tractatus shall be widely recognized and whether it will provide an appropriate practical treatment for the socio-political problems of international community.

\section{References}

[1] D. Igor (1999), The Paths of History, Cambridge: Cambridge University Press, p, 134, 232, 342.

[2] C. V. Findely, A. M. Rothney (2011), Twentieth-Century World, 7th Edition, New York: Wadsworth, p, 130, 187, 345, 349.

[3] Korab-Karpowicz, W. J. (2007), "Heidegger's Hidden Path: From Philosophy to Politics," The Review of Metaphysics, 61, pp. 295-315.

[4] Warrington W. M. (2000), Fifty Key thinkers on History, London: Rutledge, p, 123, 220, 266, 358.

[5] Plant, R. (1991), Modern Political Thought, Oxford: Basil Blackwell, p. 10.

[6] Ibn-Khaldun, M, (1956), The Muqaddimah: An Introduction to History, 3 volumes, translated by Franz Rosenthal.

[7] Toynbee, A. (1954), Heroic Ages; Contacts between Civilizations in Space, Oxford: OUP.

[8] Dowrant, W. (1950), The Age of Faith, New York: Simon \& Schuster, p. 54, 76, 542.

[9] Shahidipak, M, (2012), "Comparative Investigating in the Paradigm of Transference of Science. The Case Andalusia at the End of Medieval," International Proceedings of Economics Development \& Research, Vol. 42, p. 167.

[10] Brockelman, C, (1950), History of the Islamic People, New York: Capricorn Books, p. 159.

[11] Miquel, A, (1990), L'Islam et sa Civilisation, v. 2, p, 200.

[12] Sarton G. (1975), Introduction to the History of Sciences, London: Krieger, p, 3907, 3390, 3391.

[13] Ibn Sina's Remarks and Admonitions: Physics and Metaphysics: An Analysis and Annotated Translation (2014), transl. Shams Inati, New York: Columbia University Press. 
[14] Aristotle (2000), Politics, transl. C. D. C. Reeve, Indianapolis: Hackett.

[15] Copleston, F., C. (1990), A History of medieval philosophy, Notre Dame: University of Notre Dame Press.

[16] Gilson, E. (2019), A History of Christian Philosophy in the Middle Ages, Washington, D. C.: Catholic University of America Press.

[17] Shahidipak, M. (2018), "Averroes and his Commentary on Plato's Socio-political Philosophy," Proceedings of the XXIII World Congress of Philosophy, pp. 9-14.

[18] AL-Farabi A. N. (1980), Ary ahla madine fazalah [The Idea of Habitants of Virtual City], Byrut, p, 23, 45. 67.

[19] AL-Farabi (1991), Ehsa, Al-ulum [Division of sciences], p, 34, 67.

[20] Shahidipak, M. (2016), "Political philosophy of Islam in the Middle Ages and the beginning of the modern period, Ibn Tufail, Avempace, Averroes and Mulla Sadra", Journal of New Achievements in Humanities Studies," pp. 183-196.

[21] Shahidipak, M, (2016), A critique interpretation of the conflict between Democracy and the shape of city in the political philosophy, p. 123, 124.

[22] Jadacki, J. (2009), Polish Analytical Philosophy: Studies on Its Heritage, Warszawa: Semper, p, 52, 96, 78, 109, 158.

[23] Murawski, R. (2005) "Tarski" in: The shorter Rutledge encyclopedia of philosophy, ed. Edward Craig, Oxford: Routledge p, 1010.

[24] Wolenski, J. (2005), "Lukasiewicz", in: The shorter Rutledge encyclopedia of philosophy, ed. Edward Craig, Oxford: Routledge, p, 610.

[25] Woźniczka, M., Dariusz, D. (2007), "Polish Ideas in Philosophy", Seminar "Polish Philosophers", ETABU - Texas. Retrieved on 25 October 2020 from: https://www.researchgate.net/publication/337958047 Polish_I deas_in_Philosophy_Polish_Philosophy_and_Philosophy_in_Poland\#fullTextFileContent.

[26] Kyriaki Topidi (2019), "Religious Freedom, National Identity, and the Polish Catholic Church: Converging Visions of Nation and God", Religions, Vol. 10, 293; doi: 10.3390/rel10050293.

[27] Korab-Karpowicz, W. J. (2018), "Evolutionity—A New Age of Humanity: On the Concept of Human Evolution by Hoene Wronski”, Ruch Filozoficzny, Vol. 74, No 3, pp. 141-156.

[28] Wagner R. (2016), "Wronski's Infinities", HOPOS: The Journal of the International Society for the History of Philosophy of Science, 4 (1), doi: 10.1086/675402.

[29] Darowski, R. (2014), Philosophical Anthropology, transl. from Polish L. Darowski, Krakow: WAM.

[30] Malinowski B. (1944), Freedom and Civilization, New York: Roy Publishers, p. 58.

[31] Sobota, D. R. (2015), "Historiosophy of August Cieszkowski in the context of contemporary consciousness," Scientia et Fides, Vol. 3, No 1.

[32] A-Farabi, A. N. (1998), On the Perfect State, Lahore: Kazi Publications.

[33] Korab-Karpowicz, W. J. (2017), Tractatus Politico-Philosophicus: New Directions for The Future Development of Humankind, New York: Routledge. Numbers following quotations refer to numbered paragraphs of the book: $9.321 ; 9.213 ; 9.4231 ; 4.1 ; 4.1 .1 ; 10.5 ; 10.51 ; 6.541 ; 6.531 ; 1.1$ $1.11 ; 9.441 ; 10.02 ; 4.2 . ; 4.22 ; 10.4 ; 10.43$.

[34] Korab-Karpowicz, W. J. (2019), "The Clash of Epochs: Traditional, Modern, Postmodern, and Evolutionity", Perspectives on Political Science, Vol. 48, No 3, p. 170.

[35] Smith, B. (2006), "Why Polish Philosophy does not Exist," in: J. Jadacki \& J. Pasniczek (eds.), Poznan Studies in the Philosophy of the Sciences and the Humanities, vol. 89. pp. 19-39.

[36] Werner, K. (2020), "Philosophy in Poland: Varieties of AntiIrrationalism. A commitment to Reason Without the Worship of reason," Philosophia, Vol. 48, pp. 1-32.

[37] Outhwaite. W. and T. Bottomore (eds.) (1993), The Blackwell Dictionary of Twentieth-Century Social Thought, Oxford: Basil Blackwell. 